\title{
Commentary
}

\section{Experience with Practical Environmental Education in Primary Schools}

\author{
Manfred Fehr \\ Institute of Geography, Federal University, Uberlândia MG, Brazil
}

Email address:

mfehr@ufu.br

\section{To cite this article:}

Manfred Fehr. Experience with Practical Environmental Education in Primary Schools. International Journal of Environmental Protection and Policy. Vol. 4, No. 1, 2016, pp. 1-9. doi: 10.11648/j.ijepp.20160401.11

\begin{abstract}
This paper relates ongoing research on environmental quality in the Brazilian school universe, with analyses and results from six schools. The objective is to achieve environmental education of students through exposure to the impacts of their school on city infrastructure. In the first two schools, the work plan addressed composting of food residues from the canteen. The work in the third school included measurements of raw waste composition and destinations for sorted waste. In the fourth school, students composted biodegradable residues, sorted inert waste and delivered it to reverse logistics. In the fifth school, the scope included water and energy management. The work with this community resulted in the proposal of an environmental management system. In the sixth school, the students developed score sheets for sustainable behavior, which referred to water and energy consumption, waste production and degree of sorting and noise levels. In conclusion, this research established quantifiers to show the contribution of a school to a sustainable city.
\end{abstract}

Keywords: Composting in Schools, Environmental Behavior, Environmental Education, Environmental Management Systems, Environmental Protection, Score Sheets for Environmental Performance

\section{Introduction}

Enterprises of the production and service sectors routinely use environmental performance analyses, but its application in primary schools is uncommon.

Since 2004, the International Organization for Standardization (ISO) operates the Kid's ISO 14000 Program with the declared objectives "to develop environmental awareness among children, to teach them to implement environmental management in homes and communities and to open them to the value of networking with young people in other schools" [18]. By 2009 an estimated 210,000 children worldwide had participated and achieved a 70,000-ton reduction of $\mathrm{CO}_{2}$ emissions.

Reports from Cambodia relate efforts to involve schoolchildren in the protection of the architectural, historical and cultural site of Angkor from deterioration by tourism [19]. The authors of [22], [21] and [6] describe the importance of environmental education in the school context, but the treatments remain general. No specific procedures for environmental performance analysis are given. Author [25] defends the idea that a school is not an isolated entity. It is part of the social context of the city and as such, cannot remain inert with respect to its interaction with the municipal environment. Exactly this idea forms the basis of the present study. The query is "Does the school community know its impact on city infrastructure and what does it do to minimize it?"

UNESCO declared the decade from 2005 to 2014 the "Decade of Education for Sustainable Development" [32]. This declaration attributes special responsibilities to educational institutions worldwide. The challenge is to stimulate new attitudes towards the environment that can lead the way to sustainable nations. Authors [16] challenge the success of the UNESCO initiative when they argue, "The UN Decade of Education for Sustainable Development failed to acknowledge or challenge neoliberalism as a hegemonic force blocking transitions towards genuine sustainability."

The present study introduces the idea of measuring the environmental performance of school communities and setting voluntary benchmarks. This idea is original in the region where the schools are located.

According to [12], Brazilian primary schools have not yet assimilated the challenge put forth by UNESCO, such that, 
generally speaking, the corresponding course content has not extrapolated the classrooms. They describe the implementation of water and energy saving initiatives, but admit that this type of procedure is restricted to less than one percent of Brazilian primary schools. Those authors also state that environmental impacts of schools have become more visible due to increasing consumption of water and energy, increasing waste generation and increasing use of private means of transportation by students.

This is a natural consequence of the growing importance of the service sector in general, and the school sector in particular, to national economic performance. Here is one more justification for the present study, which quantifies the environmental impact of schools in order to make it visible to the community. Authors [24] describe an experiment with eco-literacy activities, but do not provide any quantification. The Foundation for Sustainable Development provides "on-site workshops led by field staff to train community partners in different parts of the world to create economically and environmentally sustainable programs through community assessments, grant proposal development, project design and management, financial management, and monitoring and evaluation." [13].

The ECO-Schools initiative [8] recommends environmental reviews in schools. The reviews form the basis for action plans and typically contemplate the items "Litter, Waste Minimization, School Grounds, Biodiversity, Energy, Water, Transport, Health and Well-Being, Sustaining our World." The reference stipulates that the initiative of review and actions be in the hands of students. The United Kingdom section of ECO-Schools provides detailed review procedures for primary schools [9]. The following is an example of monitoring water consumption:

"Is there a water meter to record water use in the school?

Are there push-on or self-stopping taps in the toilets?

Are there water saving devices in the toilets?

How often does the school run water-saving campaigns?

Are pupils involved in taking and displaying readings?

In addition, if so, are the results recorded on graphs and shared with the rest of the school?"

The Australian Institute of Architects adopts criteria for an environmental review in schools from the Foundation Environment Education Europe. There are seven criteria as follows [3]:

"1 litter and water management

2 hot water, insulation, radiators, electricity and heating system

3 vehicle use

4 washroom taps, toilets and rain water use

5 use of recycled paper and responsible purchasing

6 landscape and wildlife features

7 environmental education, school interior and school involvement".

In addition, the same reference lists the items related to the Schools' Environmental Assessment Method as follows:

"1 recycling facilities

2 energy rating, low- $\mathrm{NO}_{\mathrm{x}}$ combustion equipment
3 home-to-school transport policy

4 water savings and quality

5 caretaker training

6 use of recycled materials

7 site selection for new buildings

8 ventilation

9 integrated lighting controls".

The present study incorporates many of those criteria in its set of environmental performance parameters intended for targeting and competition in schools.

The project competition for schools run by The Guardian [30] specifically assigns value to projects that

"Measure the benefit to students.

Bring out ideas for improving school life.

Target long-term results.

Are transferable to other schools."

The Trust for Sustainable Living [31] runs a charity that organizes competitions for schools in a variety of environmental subjects. In 2014, it challenged students worldwide to answer the question "What does sustainable living mean to you?" and to produce a three-minute video on their school's best environmental project.

The method of key performance indicators (KPI) allows any school to choose the indicator considered most important by the community, such as the graduation rate of students and the success of finding employment after graduation [1].

Author [14] deals with Education for Sustainable Development as advocated by the UN. In quite general terms, "it should teach goals for conservation, social justice, appropriate development and democracy in order to build a society that is ecologically, socially and economically sustainable."

Authors [5] present proposals for school design that incorporates sustainability concepts. They argue that children spent most of their time in the school, and this environment ought to be inviting to them. They advocate concepts of good lighting, low energy use, good inside air quality, easy maintenance, water use efficiency, rain water harvesting and waste reduction as adamant to a sustainable school environment.

In a review paper, authors [20] state that theoretically, environmental knowledge leads to awareness and from there to behavior, which mimics the awareness. Their findings reveal that in practice, this process is not necessarily continuous. Knowledge does not always result in the pertinent behavior. In order to reach desired patterns of behavior, it is necessary to resort to direct experience. The present study uses this procedure in as much as it inverts the order of progress. It induces the community to measure the results of its behavior, which in turn will stimulate interest in acquiring knowledge. Exemplifying, the community measures its water consumption, and with this information starts asking questions about the availability of water in the city.

The Green Action Centre [15] addresses the specific subject of composting in schools. "Students can not only learn about how waste can be turned into a rich soil, but also the related environmental concerns." This experience from Canada 
provided motivation for the present study because it is perfectly applicable in Brazilian schools.

Authors [27] perform experiments in British schools about the effect of noise on classroom performance of students. They provide evidence that external as much as internal noise negatively affects memory, motivation and reading ability and that it influences the results of standardized tests and exams.

The Environmental Performance Index [10] is an initiative based on the statement "We are what we measure. It's time to measure what we want to be". It proposes to institutions that they measure their environmental impact in order to conceive plans for improvement.

The present study follows this line of thought and measures the impacts schools exert on their neighborhood and on the municipal environment generally. Students are not usually conscious of this type of impact, because school performance measurements up to now are restricted to academic achievement. The primary objective is to expose students to direct experience with identifying and measuring environmental impacts. The secondary objective is to induce environmental consciousness through the direct experience, and create the desire for acquiring the relevant knowledge. The tertiary objective is to develop environmental performance indicators in schools that guide students in the quest for improved behavior and allow for comparisons and target setting.

The foregoing references testify to the fact that competitions within the school universe are common events the world over, be it on academic or environmental topics. The present study pretends to prepare schools for this type of competition through diagnoses of their performances and the search for suitable indicators to set environmental targets.

Following personal contacts, the study proceeded successively in six schools located in Central Brazil in the municipalities of Araguari, Uberaba, Uberlândia and Ituiutaba. The study in itself represented a learning process. Starting with simple procedures like separating and composting food residues from the canteens, the scope steadily widened to include measurements of noise, water and energy consumption and degree of source separation of waste. The stipulation of dimensionless performance indicators agreed upon by the communities closed the learning cycle.

\section{Methods}

All school administrations granted permission for data collections and direct involvement of students in the various measurements and waste movement activities. On a voluntary basis, students gathered in various teams to tackle different impacts of the schools on the environment. The author's group supplied guidance, but the action remained with the students. The first two schools, located in Araguari, served as starting points of the study. Teams of students collected food scraps from the canteens and ran composting operations in open spaces of the school grounds [26]. In the third and fourth schools, located in Uberaba and Uberlândia, apart from running composting operations for food scraps, students measured the total waste of the school, determined its composition and identified correct destinations for the various components [28], [23]. In the fifth school, located in Uberlândia, the scope opened considerably. The procedure involved students as well as staff, included monitoring of water and energy consumption and established the base for an environmental management system [7]. The sixth and last school of this sequence, located in Ituiutaba, reached the highest level of quantification. Measurements taken by students included the following items:

Rate of solid waste production, degree of sorting at the source and delivery to pertinent destinations, by manual weighing of all waste items produced per day.

Water consumption and specific forms of use, by counts of valves and taps, showers, drinking fountains, hydraulic brooms and dish washing machines and times of use and analysis of water utility bills.

Energy consumption and specific forms of use through counts of lamps and appliances and times of use and analysis of energy utility bills.

Noise levels around the premises measured with decibel meter at different points and hours.

Constructed and open soil areas by manual measurement [4].

The items selected for performance evaluation closely follow those reported by [3], although no copy is attempted.

\section{Results}

Material balances for the composting operations appear in Table 1.

Table 1. Material balances of composting experiences run by students in schools 1, 2 and 4, $\mathrm{kg}$.

\begin{tabular}{lllllll}
\hline Input: & food scraps & structuring & water & Output: & sieved & product \\
\hline & material & & & rejects & 45.75 & $30 \%$ \\
\hline School 1 & 91.22 & 39.95 & 30.00 & 41.00 & 11.07 & $36 \%$ \\
School 2 & 197.85 & 65.67 & 42.00 & 57.23 & 116.44 & $46 \%$ \\
School 4 & 140.00 & 108.00 & 60.00 & 97.56 & \\
\hline
\end{tabular}

Table 2. Waste composition in school 3

\begin{tabular}{llll}
\hline & Biodegradable material & recyclable inert & rejects \\
\hline School 3 & $38.2 \%$ & $42.6 \%$ & $19.2 \%$ \\
\hline
\end{tabular}


The students learned from this balance that approximately half of the input material escapes as biogas as result of microbial activity. An exception is the compost from school 4, the humidity of which is excessive.

In school 3, students separated and weighed all waste produced, with the result shown in Table 2.

The biodegradable material originated from the canteen and lunch counters. The students composted this part, and identified reverse logistics operators who took away the dry recyclable items. The direct involvement taught students that they could recycle $80.8 \%$ of all school waste.

In the fifth and sixth schools, the scope of the study opened to move beyond waste production and include other environmental parameters. Students measured water and energy consumption, noise levels and area available for rain harvesting.

Table 3 shows the populations of these two schools.

Table 3. School population in schools 5 and 6.

\begin{tabular}{lllll}
\hline & students & teachers & service personnel & total \\
\hline School 5 & 1924 & 175 & 40 & 2139 \\
School 6 & 908 & 82 & 79 & 1069 \\
\hline
\end{tabular}

The high number of service personnel in school 6 derives from the presence of a full-day nursery.

Table 4 summarizes the environmental situation in school 5 .

Table 4. Results of measurements in school 5.

\begin{tabular}{ll}
\hline Water consumption & $3131 \mathrm{~m}^{3} /$ year \\
Energy consumption & $46.1 \mathrm{Mwh} /$ year \\
Solid waste production & 8.1 tonnes / year \\
Average noise level on premises & 65 decibels \\
Total area of school $6936.5 \mathrm{~m}^{2}$ (permeable $2841.0 \mathrm{~m}^{2}$, impermeable 4095.5 \\
$\mathrm{~m}^{2}$ ) \\
\hline
\end{tabular}

In consequence of this analysis, the author's team proposed to the school administrators, the participative development of an environmental management system (EMS) within one year by assigning specific tasks to all segments of the school community with physical and temporal targets and demands for result reporting. The proposal indicated the formation of teams consisting of teachers and groups of students for carrying out each task. The tasks initially contemplated were the following:

Water management. Scope: Monitor monthly water consumption, identify points of irresponsible use and compare to consumption at home. Time line: one year. Responsible persons: arts teachers and grade 6 students. Progress indicator: monthly reduction of utility bill.

Energy management. Scope: monitor energy consumption and identify unnecessary uses, compare with consumption at home. Time line: one year. Responsible persons: language teachers and grade 10 students. Progress indicator: monthly reduction of utility bill.

Solid waste management. Scope: Establish best practice handling procedures for all waste and compare to production at home. Time line: one year. Responsible persons: chemistry teachers and grade 5 students. Progress indicator: reduction of percentage of waste taken to landfill.

Noise control. Scope: monitor the noise levels inside and outside the school complex and determine the contribution of the school community to overall noise. Responsible persons: physics teachers and grade 8 students. Time line: one year. Progress indicator: separation of school noise from traffic noise.

Rainwater capture and use. Scope: determine to what extent rainwater could be collected and used. Time line: one year. Responsible persons: mathematics teachers and grade 9 students. Progress indicator: knowledge acquisition on the subject.

The work with students in school 6 produced the following analyses.

Solid waste production and destination.

The study identified three destinations for solid waste produced in the school.

1. biodegradable material from the canteen - destination pig farming.

2. dry packaging material - destination reverse logistics.

3. rubbish - destination landfill.

Manual measurement by weighing produced the following results:

1. biodegradable material $42.0 \mathrm{~kg} /$ day ( 5 days/week)

2. dry packaging material $8.0 \mathrm{~kg} /$ day (5 days/week)

3. rubbish $71.0 \mathrm{~kg} /$ day (5 days/week)

Total $121.0 \mathrm{~kg} /$ day (5 days/week)

The sorting of biodegradable and dry material was inadequate. Much of this type of material was present in the rubbish. The sorting ratio of $(42+8) / 121=0.413$ was subjectively considered insufficient.

The production of 121.0/1,069 $=0.113 \mathrm{~kg} /$ (person*day) was considered acceptable for the full-day school context and additive to home production. No literature data are available on school waste production for comparison. The number 0.113 is an initial value open to improvement through environmental education activities. On a nation-wide basis, the solid waste production in Brazil in 2013 stood at $1.041 \mathrm{~kg} /$ (person*day) [2]. This indicates that production in the school (or elsewhere in the workplace) amounts to $10.9 \%$ of total waste produced by people. As for the sorting ratio, experiments reported from apartment buildings produced numbers in the range of 0.670 to 0.900 as consequence of intensive coaching [11]. They provide a reference for targeting in the school.

Energy consumption and types of use

The school community consumes energy with lighting and with appliances. The light bulbs present in the institution were the following:

441 bulbs of $20 \mathrm{w}$

819 bulbs of $40 \mathrm{w}$

1 bulb of $100 \mathrm{w}$

85 bulbs of $250 \mathrm{w}$

16 bulbs of $400 \mathrm{w}$

total bulbs 1,362 , total power $69,330 \mathrm{w}$.

The appliances were shop equipment, computers, cloth and 
dishwashers and dryers, pumps, electric showers and control circuits. The diagnosis estimated the times of use of all bulbs and appliances and arrived at the following monthly consumption: lighting $7,787 \mathrm{kwh}+$ appliances $6,727 \mathrm{kwh}=$ total $14,514 \mathrm{kwh}$.

This number coincided with the monthly energy bill received from the electric utility company for April 2011. The contracted power demand was $55 \mathrm{kw}$. In April 2011, the maximum demand actually reached $64 \mathrm{kw}$, which generated a fine of $28 \%$ on the energy bill. This fact demonstrated that the school administration did not exert control over the contracted power usage.

As energy consumption parameter, the study produced the number of $14,514 \mathrm{kwh} /$ month * $(1 \mathrm{month} / 20$ working days $) *$ $(1 / 1,069$ persons $)=0.679 \mathrm{kwh} /($ person*day $)$ in the school, which is an initial value for discussion and future targeting by the school community.

\section{Water consumption and points of use}

Water is consumed in the canteen for food preparation and dishwashing, in drinking fountains, in toilets, in the nursery for hygiene and washing, in house cleaning and in irrigation of green spaces. The total consumption is provided by the main hydrometer, which serves the utility company for billing. From the utility bills for 2010 and 2011, the mean monthly consumption was $1,067 \mathrm{~m}^{3} /$ month. This excludes the months without school activity. In terms of individual daily consumption, this reduces to the water use parameter of $1,067,000$ liters/month * (1 month / 20 active days) * (1 / $1,069$ persons $)=50$ liters / (person*day) in the school.

This value is high due to the type of school with nursery and canteen. The average water consumption in homes of this city is 180 liters / (person*day) [33]. As the consumption is additive, the numbers indicate that persons who frequent the school consume $180+50=230$ liters / day.

The utility company bills sewage collection and treatment as $70 \%$ of water consumption. This flow cannot be measured. Accepting the fraction indicated, the sewage parameter of the school would be $50 * 0.7=35$ liters / (person*day).

\section{Rain water harvesting}

Storm water catchment had never been considered in this school. The present study quantified the possibilities and provided numbers for discussion. The mean annual precipitation in the city is $1,432 \mathrm{~mm}$ [17]. The school has $4,898 \mathrm{~m}^{2}$ of roof area available for capture. Presently, all rainwater runs off to a nearby creek. The possible annual catchment from roofs is $4,898 \mathrm{~m}^{2} * 1.432 \mathrm{~m}=7,014 \mathrm{~m}^{3} /$ year. The water consumption as calculated above is $1,067 \mathrm{~m}^{3} / \mathrm{month}$ or $8,536 \mathrm{~m}^{3} /$ year ( 8 months with school activities). This means that rain water could attend to more than $80 \%$ of water use, specifically to non-potable water uses, such as toilets, house cleaning and irrigation. The metering system does not allow for discrimination between potable and non-potable uses. Additional hydrometers would be required. The present rain contribution ratio is zero, but the target could be 7,014 / 8,536 $=0.822$, which indicates the fraction of water use that rain harvesting could provide if the corresponding equipment were installed. The concept of sustainable school design of [5] supports and recommends this type of installation.

Noise levels

The school is located in what the law on noise defines as a mixed area, predominantly residential with a few commercial establishments. For this type of urban area, the law limits noise levels to 55 decibels (db.) during the day and 50 decibels (db.) at night [29]. This research verified noise levels in all parts of the school with a decibel meter. The noise was within the established limits in all sectors, except for the workshops with $67 \mathrm{db}$ and the gym with $56 \mathrm{db}$. It will be relatively easy to correct those excesses. The noise excess ratio is $67 / 55-1=$ 0.218 .

\section{Summary of parameters considered for evaluation}

For ease of discussion and argumentation, the parameters experimentally determined are summarized in Table 5. They are divided into positive and negative impacts. Positive impacts refer to parameters to be maximized. Negative impacts refer to parameters to be minimized. As this type of measurement had never been done in the school, the community, students as much as staff, were not knowledgeable about their impact on the municipal infrastructure. Rainwater harvesting is not included because it is a design parameter not improvable with behavior patterns.

Table 5. Results of measurements in school 6.

\begin{tabular}{ll}
\hline Positive impacts: & \\
\hline $\begin{array}{l}\text { solid waste sorting ratio } \\
\text { Negative impacts: }\end{array}$ & 0.413 sorted waste / total waste \\
solid waste production & $0.113 \mathrm{~kg} /$ (person*day) \\
energy consumption & $0.679 \mathrm{kwh} /$ (person*day) \\
water consumption & 50 liters / (person*day) \\
noise excess ratio & 0.218 noise fraction above legal limit \\
\hline
\end{tabular}

\section{Discussion}

As indicated in the Introduction, the study represented a learning process. Solid waste is the most visible environmental impact. It was the natural starting point for all measurements. The work in the first four schools demonstrated the possibility of recycling more than $80 \%$ of it through source separation, composting and reverse logistics. Table 2 shows that only $19.2 \%$ of all school waste is not recyclable. To the school community, this was an unexpected result. It stimulated new ways of thinking about waste. The composition in Table 2 is typical of schools where paper is the main consumption item. In households, the biodegradable fraction is in the order of $65 \%$ [11]. The contribution of the study to sustainable waste management practices lies in the source separation, which allowed for delivering each fraction to the correct destination. Composting on the school grounds provided to students the satisfaction of making a product out of material that previously went to the landfill. The separation of dry material provided the challenge of marketing the clean items, a procedure that required contacts with reverse logistics operators. The experience of direct involvement with measureable results induced students to adjust their behavior and learn about the schools' interactions with municipal waste management. 
The measurements of water and energy consumption in schools 5 and 6 introduced the students to reading and interpreting bills from the utility companies. This was another completely new challenge, which proved to be a learning tool. Through this exercise, students became aware of their school's presence in the general municipal infrastructure. They started to reflect about the quantities of water and energy available in the city and about conscious use of these resources.

The proposal of an environmental management system in school 5 brought the community in contact not only with the environmental quality in the city, but also with best practices in enterprises and organizations worldwide. The permanent teams formed in the school produced the sense of responsibility. As an example, the Arts teacher and the class of grade 6 students, whoever they might be in any particular year, had to assume the responsibility of monitoring the use and waste of water and of checking the monthly utility bills in order to measure their progress. Omissions were out of the question.

The community of school 6 started to use Table 5 as reference for discussion and targeting improvements. The interaction with the municipal infrastructure is apparent again. The sorting ratio of waste measures the amount that is recycled through reverse logistics and does not go to the landfill. The Table has taken the guesswork out of environmental performance evaluation. Precisely defined numerical values are now available to school administrators for verification and steady improvement. The school community can set its own collective targets and document its numerical progress. As all parameters are defined clearly in terms of easily measurable values, they can be readily adopted by schools anywhere. This is the original contribution of the present study to environmental performance determination in schools. It is in line with the requirement for transferability of school projects supported by [30].

The noise excess index is the simplest candidate for correction. Adequate instructions to the workshop personnel solve the problem. Authors [27] stress the importance of this parameter and provide evidence of the negative impact of noise on classroom performance. The parameters referring to solid waste are controllable up to a certain limit. Administrative talent will provide instructions and examples for improvement. The sorting ratio is the first candidate for intervention. In city residences, [11] attained values in the range of 0.670 to 0.900 . This range presents itself as reference for imitation.

Finally, the energy and water consumption parameters are the most visible performance indicators, because the utility bills remind the administration month after month. Design changes may help. Modern water taps and toilet flushing devices as well as solar panels for water heating and electricity generation are readily available. Savings will result from new technologies and from educational measures. These two items are of direct interest to the city administration, who might consider providing specific instructions to all schools. There are 77 schools in the city of Ituiutaba with a total student population of 7,172 [33]. Table 5 will show the city administration, e.g. that the daily water consumption in this universe reaches $7,172 * 50=358,600$ liters. Depending on the supply situation in the municipality, coercive measures may come into play.

The parameters address all stakeholders of the environmental engineering and management community. Engineers will design and install solar panels, rain harvesting equipment and water saving devices. Managers, like school principals and municipal department heads will organize the solid waste movement. Table 5 offers to all of them data for comparison and extrapolation, and allows for the establishment of targets. As the community itself runs the regular diagnoses, it is exposed to what [20] refer to as direct experience, which is a more powerful tool for building consciousness and forming patterns of behavior than indirect experience like lectures.

The parameters in Table 5 have dimensions. This makes it complicated to perceive the overall performance improvement achievable by working individually on any one parameter. Therefore, the author proposes transforming the parameters into fractions of ideal values, such that one single performance index defines the situation of the school. The procedure is as follows.

A reference value is established for each parameter. For the positive impacts, the reference is placed in the denominator and the measured value in the numerator. For the negative impacts, the reference is placed in the numerator and the measured value in the denominator. Each fraction, then, aspires to unity as the positive impacts increase and the negative impacts decrease, and the average value of all fractions represents the overall performance index.

The reference values proposed for school 6 are shown in Table 6. They are guides for the school community in the quest for continuous improvement of its own index. Obviously, the choice of the references is subjective as long as no universal, national or municipal indicators are available. Every school has to exercise discretion when defining its reference values. If the municipal administration pretends applying the index method to all schools, then it has to stipulate municipal reference values or key performance indicators (KPI).

Table 6. Reference values of environmental performance parameters. for school 6, established by debate within the community and subject to modification from experience.

\begin{tabular}{ll}
\hline Positive impacts: & \\
\hline $\begin{array}{l}\text { solid waste sorting ratio } \\
\text { Negative impacts: }\end{array}$ & 0.670 sorted waste / total waste \\
solid waste production & $0.100 \mathrm{~kg} /$ (person*day) \\
energy consumption & $0.550 \mathrm{kwh} /$ (person*day) \\
$\begin{array}{l}\text { water consumption } \\
\text { existing noise }\end{array}$ & $\begin{array}{l}40 \text { liters / (person*day) } \\
55 \text { highest db. measure in the school }\end{array}$ \\
\hline
\end{tabular}

Tables 5 and 6 allow for the calculation of the overall performance index of the school. As illustration of a positive impact, the solid waste sorting index is $0.413 / 0.670=0.616$. The reference appears in the denominator. As illustration of a negative impact, the water consumption index is $40 / 50=$ 0.800 . The reference appears in the numerator. 
Table 7 shows the complete calculation of a possible overall index based on the subjective reference values stipulated.

Table 7. Present environmental behavior index of school 6.

\begin{tabular}{ll}
\hline Positive impacts & \\
\hline $\begin{array}{l}\text { Solid waste sorting index } \\
\text { Total }\end{array}$ & $0.413 / 0.670=0.616$ \\
Negative impacts & 0.616 \\
Waste production index & $0.100 / 0.113=0.885$ \\
Energy consumption index & $0.550 / 0.679=0.810$ \\
Water consumption index & $40 / 50=0.800$ \\
Noise index & $55 / 67=0.821$ \\
Total & $=3.316$ \\
Overall performance index $(0.616+3.316) / 5=0.786$ \\
\hline
\end{tabular}

Table 7 is the typical result of a practical approach to measuring and influencing environmental behavior. The method has drawn on the experience of [8] and [3] and has adapted them to the specific local context.

It is an initial proposal subject to modification through discussions and debates within the school community. This is a direct consequence of the absence of universal environmental KPI for schools. The present study contributes its modest share of arguments to compose a common set of KPI at least at the municipal level. The index represents a reference towards which the community can work in preparation for national and international contests. It depends on the adoption of realistic long-term behavioral targets agreed upon by all members of the community as consequence of environmental education. This represents the most important outcome of the study. It fosters the idea that present-day school life is not only about classroom performance, and it puts into practice the teachings of the Environmental Performance Index [10], which state, "We are what we measure".

The following hypothetical example illustrates the type of progress that could be targeted for one year. The administration implements an environmental education program to involve students in pursuing the targets waste sorting ratio 0.600 , energy consumption $0.590 \mathrm{kwh} /$ (person*day), water consumption 45 liters / (person*day), excess noise level 0.000 . Upon attaining those targets, the original environmental behavior index of Table 7 would change to that shown in Table 8.

Table 8. Hypothetical environmental behavior index after attaining yearly target.

\begin{tabular}{ll}
\hline Positive impacts & \\
\hline Solid waste sorting index & $0.600 / 0.670=0.896$ \\
Total & 0.896 \\
Negative impacts & $0.100 / 0.113=0.885$ \\
Waste production index & $0.550 / 0.590=0.932$ \\
Energy consumption index & $40 / 45=0.889$ \\
Water consumption index & $55 / 55=1.000$ \\
Noise index & $=3.706$ \\
Total & $/ 5=0.920$ \\
Overall behavior index $(0.896+3.706)$ & \\
\hline
\end{tabular}

With the elaboration and dissemination of monthly progress reports, the school community follows the improvements achieved and can find stimulation to contribute. In case of the hypothesis at hand, and with reasonable collective effort, the environmental performance index could move from 0.786 (Table 7) to 0.920 (Table 8 ) within one year. This procedure represents a powerful educational tool in the hands of dedicated school administrators. Table 8 provides information on the main remaining bottlenecks. Water consumption and waste production have the lowest values. The index procedure brought those facts to the attention of the school community.

This hypothetical example illustrates how a school community can agree upon a set of targets in order to challenge itself and derive satisfaction from new patterns of behavior.

Although in an ideal case, KPI for schools are established at the municipal or regional level, nothing prevents individual schools from taking the initiative and providing benchmarks even in the absence of those KPI. In fact, the idea of the present study was exactly this: induce bottom-up procedures that might provoke actions by municipal or regional administrators. The method of index targeting is in accordance with the project competition parameters of The Guardian [30] in as much as it brings out ideas for improving school life, targets long-term results and is transferable to other schools. The relevance of the index resides in its simplicity. A single number with known significance conveys to the community continuous information on its progress in pursuing behavioral targets.

The practice of regular measurements to update the diagnosis is in accordance with [20] who concede that direct experience is more effective in producing behavior change than indirect experience like lectures on the environment.

\section{Conclusions}

Students are not conscious of the impact their school exerts on the municipal environment, because school performance measurements up to now are restricted to academic achievement.

Experiments have demonstrated to students that $80 \%$ of school waste is recyclable.

Students have been involved directly in waste sorting and composting.

Students learned how to make compost as a product and how to market recyclable items.

Through measurement and monitoring of water and energy consumption, students have become knowledgeable about availability and constraints.

An environmental performance index has been developed for purposes of targeting improvements in the school proper and of inducing competition between schools

Performance parameters on a "per person per day" basis have been transformed into fractions of ideal values in order to provide a framework for comparisons and target settings in the school universe. This is the theoretical contribution of the study to school performance analysis.

The definition of an environmental performance index as fractional approach to perfection simplifies comparative 
performance evaluation.

The general dimensionless nature of the proposed index gives it universal significance and applicability.

The index method represents a benchmarking experience in the region for evaluating environmental impacts of schools and is transferable to other schools.

The most appropriate way to close this report is to repeat the statement from the Environmental Performance Index [10]: "We are what we measure. It's time to measure what we want to be", and by extending an invitation to school communities worldwide to use the method proposed here to measure what they want to be.

\section{Acknowledgements}

This research received support from the Brazilian Research Council CNPq through grant 303480/2013-0-PQ.

\section{References}

[1] About Money

http://management.about.com/cs/generalmanagement/a/keyper findic.htm (accessed 201508 24).

[2] ABRELPE 2013, Eleventh Overview of Solid Waste in Brazil (in Portuguese)

http://www.abrelpe.org.br/Panorama/panorama2013.pdf

(accessed 201408 17).

[3] AIA Australian Institute of Architects, Environment Design Guide November 2003

http://www.yourbuilding.org/library/1_GEN23.pdf (accessed $20150824)$.

[4] Andrade, V. S. C. S., Fehr, M. 2016, Search for objective environmental performance indicators of primary schools, Benchmarking - An International Journal, Emerald Insight, ISSN 14635771 Accepted for publication 201511 11, vol. 23 No. 2 pp. xxx.

[5] Brković, M., Milošević, P., 2012, Sustainable Schools as 3D Textbooks: Safeguards of Environmental Sustainability, FACTA UNIVERSITATIS, Series: Architecture and Civil Engineering Vol. 10, No 2, pp. 179 - 191, DOI: 10.2298/FUACE1202179B UDC 727.1: 502.131.1 =111 http://facta.junis.ni.ac.rs/aace/aace201202/aace201202-06.pdf (accessed 201409 23).

[6] Coimbra, JA., 2004, A Linguagem e Percepção Ambiental (Language and environmental perception), in: PHILIPPI JUNIOR, A., ROMÉRO, MA., BRUNA, GC. (Org.). Curso de Gestão Ambiental (Course on Environmental Management). Manole Publishers, Barueri BR, pp. 527-570.

[7] Crosara, R., Fehr, M., 2011, Creating an environmental management system in a school community. Journal of Research in International Business and Management, International Research Journals vol. 1 no. 8 pp. 245-250, ISSN 22510028.

[8] ECO-Schools

http://www.eco-schools.org/menu/process/seven-steps (accessed 20141020 ).
[9] ECO-Schools review manual for UK schools http://www.eco-schools.org.uk/gettingstarted/environmentalre view (accessed 20141020 ).

[10] Environmental Performance Index http://www.epi.yale.edu/indicators-in-practice/making-grade-i ndicators-sustainability-colleges-and-universities (accessed $20141020)$.

[11] Fehr, M., 2014, The management challenge for household waste in emerging economies like Brazil: realistic source separation and activation of reverse logistics, Waste Management \& Research, SAGE Publications, vol. 32 no. 9 pp. 32-39 http://www.dx.doi.org/10.1177/0734242X14541985.

[12] Feres, YN., Antunes, FZ., 2007, Gestão Ambiental em Instituições de Ensino (Environmental Management in Educational Institutions), Curitiba. Unpublished Research Report.

[13] FSD Foundation for Sustainable Development http://www.fsdinternational.org/about/mission (accessed 2016 $0123)$.

[14] Gough, A., 2006, Sustainable schools in the UN decade of education for sustainable development: Meeting the challenge? Southern African Journal of Environmental Education, vol. 23 pp. 48-63.

[15] GAC Green Action Centre http://greenactioncentre.ca/live/school-composting/ (accessed 20150123 ).

[16] Huckle, J, Wals, AEJ, 2015, The UN Decade of Education for Sustainable Development: Business as usual in the end, Environmental Education Research, vol. 21 no. 3 pp. 491-503.

[17] INMET 2014 http://www.inmet.gov.br/portal/index.php?r=clima/faixaNorm alPrecipitacaoTrimestral (accessed 201410 24).

[18] ISO 2004, Kid's ISO 14000 Program ISBN 9267103881 http://www.iso.org/iso/pressrelease.htm?refid=Ref895 (accessed 201406 20) http://www.artech.or.jp/english/kids/envedu/index.html (accessed 20140620 ).

[19] ISO 2005, Cambodian schoolchildren put EMS basics into practice to preserve Angkor site, http://www.iso.org/iso/pressrelease.htm?refid=Ref952 (accessed 20140620 ).

[20] Kollmuss, A., Agyeman, J., 2002, Mind the gap: Why do people act environmentally and what are the barriers to proenvironmental behavior, Environmental Education Research vol. 8 issue 3 pp. 239-260.

[21] Leite, ATA., Medina, NM., 2000, Educação Ambiental: Curso Básico a Distância (Environmental Education: Distance Learning Course) part 1 first edition, Ministry of the Environment, Brasília, DF, Brazil.

[22] Mamede, F., Leite, ALA., 1999, Environmental education for sustainable development (in Portuguese), Ação Ambiental, Federal University at Viçosa, Brazil, vol. 2, issue 8, pp. 18-20.

[23] Melo, M. R., Fehr, M., 2010, Management of institutional discards; how to eliminate the landfill option (in Portuguese), Scientia Plena, Associação Sergipana de Ciência, Aracajú BR vol. 6 no. 7 article 3, ISSN 18082793. 
[24] Pires, JDTS., Fonseca, MMCS., Smith, RE, Philippi, LS., 2008 Integração entre gestão e educação ambiental na Escola de Ensino Básico Getúlio Vargas (Integration of school administration and environmental education). EXTENSIO Revista Eletrônica de Extensão. Número 6.

[25] Oyafuso, A., 2004, Teaching Program (Plano Escolar) (in Portuguese), 4th edition, Biruta Publishers, São Paulo, Brazil.

[26] Santos, H. M. N., Fehr, M., 2008, Environmental education through composting of food residues in schools of Araguari (in Portuguese), Caminhos de Geografia, IG-UFU, Uberlândia BR, vol. 9 no. 25 pp. 65-86, ISSN 16786343.

[27] Shield, B. M., Dockrell, J. E., 2008, The effects of environmental and classroom noise on the academic attainments of primary school children, The Journal of the Acoustical Society of America, vol. 123, issue 1, pp. 133-144, http://dx.doi.org/10.1121.1.2812596.
[28] Silva, A. G., Fehr, M., 2013, How students can handle school waste: a case study (in Spanish), Revista AIDIS de Ingeniería y Ciencias Ambientales: Investigación, Desarrollo y Práctica. vol. 6 no. 2 pp. 65-71, ISSN $0718378 X$.

[29] State of Minas Gerais, Brazil, 1990, Law N ${ }^{0} 10100 / 1990$ section 2 .

[30] The Guardian http://www.theguardian.com/teacher-network/zurich-school-c ompetition/schools-competition-overview (accessed 201508 24).

[31] Trust for Sustainable Living http://www.livingrainforest.org/charity (accessed 20151103 ).

[32] UNESCO, 1999, Education and Population Dynamics: Mobilizing Minds for a Sustainable Future, EPD-99.

[33] Wikipedia, http://en.wikipedia.org/wiki/Ituiutaba (accessed $20141021)$. 